\title{
Comparative Study on the Effectiveness of a Health Promotion Program Using School Forest and a Traditional School-based Health Promotion Program in Elementary Students
}

\author{
Insook Lee ${ }^{1} \cdot$ Kyung-Sook Bang ${ }^{1} \cdot$ Sungjae Kim ${ }^{1} \cdot$ Heeseung Choi ${ }^{1} \cdot$ Juna Lee $^{2}$ \\ ${ }^{1}$ College of Nursing, The Research Institute of Nursing Science, Seoul National University, \\ ${ }^{2}$ Department of Nursing, Graduate School of Seoul National University
}

\begin{abstract}
Purpose: This study compared the effects of two six-week school-based intervention programs - a health promotion program using a school forest and a traditional school health promotion program (TSHPP) - on physical and mental health among elementary school students. Methods: A total of 73 students participated in the study: 21 students in the 6-week school forest program conducted in a rural area and 52 students in the 6-week TSHPP conducted in an urban area. Children's health promotion behavior, depression and hyperactivity were measured using a self-report questionnaire. To assess children's physical health, body mass index (BMI), body fat percentage, and heart rate variability (HRV) were used. Results: Overall, both intervention programs improved participants' physical and mental health. Both programs significantly decreased the body fat percentage; this effect was more prominent in the TSHPP group. Only the TSHPP significantly decreased the participants' BMI after the intervention. The school forest group showed significantly improved relaxation and diminished hyperactivity; the TSHPP group showed significantly improved health promoting behavior and social relationship after the intervention. Comparing the two groups'post-pre difference scores, the two groups significantly differed only in social relationship. Both group showed significantly improved depression after the intervention. Conclusion: These findings support the effectiveness of these 6-week school-based health promotion programs in improving physical and mental health among school-aged children.
\end{abstract}

Key Words: Forests, Health promotion, Child, School health services

\section{INTRODUCTION}

Early childhood is a crucial period in the process of human development, in which physical, mental and social development takes place in balance. Particularly regarding establishing good health habits, which affect subsequent health status in later life, childhood is regarded as an important period. Accordingly, many attempts have been made to improve child's health behavior through various school-based health promotion programs; these programs have reported positive effects on physical[1-3], mental[4], and social health[5] among school-aged children.

It remains the case, however, that almost $20 \%$ of elementary school students are overweight in Korea[6], and experiencing high level of stress and depression[7]. Interpersonal problems (e.g. bullying) are also serious at this age[8]. Though various programs targeting both

\footnotetext{
Corresponding author: Kyung-Sook Bang

College of Nursing, Seoul National University, 103, Daehak-ro, Jongno-gu, Seoul 03080, Korea.

Tel: +82-2-740-8819, Fax: +82-2-765-4103, E-mail: ksbang@snu.ac.kr

- This work has been supported by a research grant from the Korea Forest Service(No. S211214L010140).

Conflicts of interest: The authors declared no conflict of interest regarding the publication of this paper.

Received: Jul 15, 2016 / Revised: Aug 17, 2016 / Accepted: Aug 17, 2016
}

This is an open access article distributed under the terms of the Creative Commons Attribution Non-Commercial License (http://creativecommons.org/licenses/ by-nc/3.0), which permits unrestricted non-commercial use, distribution, and reproduction in any medium, provided the original work is properly cited. 
physical and mental health among school-aged children have been developed and implemented, health promotion programs utilizing existing resources or natural environment in the community is still limited.

Currently, nature-related activities are known to positively affect physical and mental health at various ages. Exposure to a natural forest environment, or forest walking, has been found to improve perceived general health[9] and alleviate stress and depression through psychological relaxation in healthy adults [10-12]. Recently, the Korean government of forest service has constructed school forest nationwide, expecting its benefits to students' physical and mental health. In previous study, the forest experience made a great help to elementary school students to have a respect and dignity of life and recognize the importance of the natural environment [13]. In other study, it demonstrated the associations between the characteristics of school forest and students' satisfaction [14]. However, experimental studies testing the effects of school forest on child's health has not been conducted.

Filling this gap in the available information, the present study was designed to compare the effects of two different school-based intervention programs-a school-based health promotion program utilizing school forest (the"school forest program") in one rural elementary school and a traditional school-based health promotion program (TSHPP) in one urban elementary school-regarding physical and mental health among elementary school students. We hypothesized that (1) After providing programs, physical and mental health of children will be significantly improved in both of school forest program group and TSHPP group. (2) The difference in physical and mental health between pre and post program will be greater in school forest program group than those of TSHPP group.

\section{METHODS}

\section{Study Design}

This study used a quasi-experimental, non-equivalent pretest-post design to compare the effects of the school forest program and the TSHPP.

\section{Participants}

Considering the accessibility and positive effect of exposure to forest on health[9-14], we selected one elementary school with school forest located in rural area for the school forest program. In addition, we selected another elementary school located in urban area for the TSHPP. Power analysis using Cohen's (1988) method was performed to calculate a proper sample size for the study. As a result, 54 participants (27 subjects in each group) were required to perform Mann Whitney $\mathrm{U}$ test at the level of -0.05 , effect size 0.8 , power 0.8 , and two independent variables.

Participants were 73 elementary school students (4th and 5th grade) recruited from one rural and one urban elementary school using convenient sampling. 21 students from rural area were assigned to the school forest program (the "school forest group"); 52 students from urban area were assigned to the TSHPP (the "TSHPP group").

\section{Instruments}

Four scales were used to measure children's psychosocial health status and health promotion behavior. Depression was measured using the Kovacs'Children's Depression Inventory[15], which was modified by Cho \& Lee[16] in Korea. This scale is composed of five subcategories: depressed mood ( 5 items), behavior problems ( 7 items), loss of interest (7 items), self-degradation (4 items), and physiological symptoms (4 items). Responses used a 3-point scale $(0,1$, or 2$)$. This scales' reliability, as Cronbach's $\alpha$, was .91 in this study.

Hyperactivity was measured using the Conners-Wells' Adolescent Self-report Scale-Short form (CASS-S), modified by Bahn et al.,[17] in Korea. This scale is composed of 27 items; responses used a 4-point scale $(0,1,2$, or 3$)$. Higher scores indicated greater hyperactivity. This scale's Cronbach's $\alpha$ was 89 in this study.

Social relationship was measured using the scale developed by Bae[18] and modified by Choi[19]. This scale is composed of seven subcategories: diligence (5 items), sociability (5 items), autonomy (5 items), rule-adherence (5 items), responsibility (5 items), cooperation (5 items), and sympathy (5 items). Responses used a 4-point scale (1, 2, 3, or 4). This scale's Cronbach's $\alpha$ was .86 in this study.

Health promotion behavior was assessed using a 36-item questionnaire developed by Walker et al.,[20] and translated by Kim \& Chung[21]; 11 items for eating habits, 8 items for exercise habits, 7 items for healthy living conditions, 5 items for personal relations, and 5 items for self-realization[20,21]. This scale's Cronbach's $\alpha$ was .91 in this study.

\section{Physiological Measurement}

To assess changes in physiological health, we measured body weight, height and body fat percentage with a body 
composition analyzer (J10, Biospace, Seoul, Korea). Body mass index was calculated by dividing the child's body weight $(\mathrm{kg})$ by the square of the child's height $\left(\mathrm{m}^{2}\right)$. We also measured participants' body fat percentage, as an indicator of the proportion of body fat to body weight.

In addition, heart rate variability (HRV) was measured using a HRV measurement device (LXC3203, LAXTHA, Daejeon, Korea). Measurements of HRV were performed during daytime in a separate room. Participants were asked to remain seated and quiet with their eyes closed for five minutes while HRV was measured. Regarding HRV analysis, low frequency (LF) refers to sympathetic nerve activation, and high frequency (HF) refers to parasympathetic nerve activation, indicating the participant's level of relaxation[22].

\section{Description of Intervention Program}

School forest program and TSHPP were developed by modifying the program developed by Lee et al.,[23] for school-aged children. They were 6-week programs intended to improve physical and mental health among the 4 th and 5th grade of elementary school students. Both programs were administered once a week for six weeks during regular class hours. The program consisted of three physical health promotion sessions and three mental health promotion sessions. Physical health sessions focused on increasing health promoting behaviors including healthy diet, exercise, and regular sleep habits. Mental health promotion sessions addressed self-reflection and understanding others' perspectives, communication skills, and emotional regulation (Table 1).

\section{Study Procedure}

The present study was approved by the Institutional Review Board of S. university (Approval No.: 2013-64). Regarding the present study, one elementary school from a rural area and one elementary school from an urban area were selected; these provided participants for the school forest group and the TSHPP group, respectively. This group allocation was based on the accessibility of school forest.

After obtaining approval from the schools' principals and health teachers, we distributed information packages providing a full explanation of the purpose, content, and format of the programs to students and their parents. Parental written consent and child assent were obtained before collecting baseline data. Participants were assured of confidentiality, and informed that they could withdraw from the study at any time.
In both groups, we provided intervention sessions once a week for 6 weeks (Table 1). Each intervention session proceeded for 45 minutes during class hours. The pretest was performed at the end of March 2014 before the first intervention session; the posttest was carried out in June 2014, after the last intervention session. Data were collected by well-trained research team members who thoroughly understood the study procedure. It took approximately $30 \mathrm{mi}-$ nutes for participants to complete the self-administered questionnaire, and complete the body composition test and HRV. Results of the physical and mental health measures were provided to the parents and children.

\section{Data Analysis}

Statistical analysis was performed using SPSS version 21.0. To examine baseline differences between the two groups, homogeneity tests were performed using independent t-test and Mann Whitney U test. To test the hypothesis 1 , the differences between pre and posttest in each group were analyzed using paired t-test. In addition, for testing hypothesis 2 , the effects of the two intervention programs on health were analyzed using an independent t-test and Mann Whitney $\mathrm{U}$ test. The significance level was set at $p<.05$.

\section{RESULTS}

\section{Homogeneity Test between the Two Groups}

No significant differences were found in demographic characteristics and dependent variables between the two groups, except in depression (Table 2). Children in the TSHPP group reported significantly higher levels of depression than those in the school forest group at baseline $(\mathrm{t}=-2.45, p=.014)$.

\section{Changes of Pre and Post Programs in Each Group}

In each of two groups showed significant decreases in body fat percentage after the 6-week intervention; this change was greater in the TSHPP group than the school forest group $(\mathrm{t}=2.96, p=.004)$. Only the TSHPP group showed a significant decrease in BMI after the intervention. The school forest group also showed a decreased mean LF/HF ratio and heart rate $(\mathrm{HR})$ after the intervention, though only the change in mean HR was statistically significant $(\mathrm{t}=$ $-3.67, p=.002$ ).

Both groups showed significant improvement in depression scores after the intervention. In addition, children in 
Table 1. Group Activities for Each Session

\begin{tabular}{|c|c|c|c|c|c|c|c|}
\hline \multirow{2}{*}{ Domain } & \multirow{2}{*}{ Session } & \multirow{2}{*}{ Topic } & \multirow{2}{*}{$\begin{array}{l}\text { Homework } \\
\text { (both groups) }\end{array}$} & \multicolumn{2}{|c|}{ School forest group } & \multicolumn{2}{|c|}{ TSHPP group activities } \\
\hline & & & & Activities & Details & Activities & Details \\
\hline \multirow[t]{3}{*}{$\begin{array}{c}\text { Physical } \\
\text { health }\end{array}$} & 1 & Eating habits & Diet diary & $\begin{array}{l}\text { - Lecture in } \\
\text { classroom }\end{array}$ & $\begin{array}{l}\text { - Learning a proper } \\
\text { eating habit } \\
\text { - Learning the types } \\
\text { of nutrients }\end{array}$ & $\begin{array}{l}\cdot \text { Lecture in } \\
\text { classroom }\end{array}$ & $\begin{array}{l}\text { - Learning a proper } \\
\text { eating habit } \\
\text { - Learning the types } \\
\text { of nutrients }\end{array}$ \\
\hline & 2 & Exercise habits & $\begin{array}{l}\text { Using health } \\
\text { calendar \& } \\
\text { stickers }\end{array}$ & $\begin{array}{l}\cdot \text { Climbing small } \\
\text { mountain } \\
\cdot \text { Smelling plants } \\
\cdot \text { Drawing sound } \\
\text { map }\end{array}$ & $\begin{array}{l}\text { Smelling plants and } \\
\text { hearing the sound } \\
\text { in the mountain } \\
\text { - Drawing a map. } \\
\text { "Where does the } \\
\text { sound come from?" }\end{array}$ & $\begin{array}{l}\text { Exercise in } \\
\text { classroom }\end{array}$ & $\begin{array}{l}\cdot \text { Learning the } \\
\text { benefits of exercise } \\
\text { - Breathing, } \\
\text { relaxation, and } \\
\text { stretching in a } \\
\text { classroom }\end{array}$ \\
\hline & 3 & Sleep habits & & $\begin{array}{l}\cdot \text { Lecture \& quiz } \\
\text { in outdoors }\end{array}$ & $\begin{array}{l}\text { - Learning a proper } \\
\text { sleeping habit. } \\
\text { Solving OX quiz in } \\
\text { school forest }\end{array}$ & $\begin{array}{l}\text { - Lecture \& quiz } \\
\text { in classroom }\end{array}$ & $\begin{array}{l}\text { - Learning a proper } \\
\text { sleeping habit } \\
\text { - Solving OX quiz in } \\
\text { a classroom }\end{array}$ \\
\hline \multirow[t]{3}{*}{$\begin{array}{l}\text { Mental } \\
\text { health }\end{array}$} & 4 & $\begin{array}{l}\text { Self-reflection, } \\
\text { understanding } \\
\text { others' } \\
\text { perspectives }\end{array}$ & & $\begin{array}{l}\text { Planting a tree } \\
\text { with friends in } \\
\text { school forest }\end{array}$ & $\begin{array}{l}\text { - Role playing to be a } \\
\text { tree with friends } \\
\text { (leaps, stream, and } \\
\text { roots) }\end{array}$ & $\begin{array}{l}\text { Emotion card } \\
\text { game in } \\
\text { classroom }\end{array}$ & $\begin{array}{l}\text { - Reading friends' } \\
\text { face, and guessing } \\
\text { their emotion }\end{array}$ \\
\hline & 5 & $\begin{array}{l}\text { Communicating } \\
\text { with peers }\end{array}$ & & $\begin{array}{l}\text { Communication } \\
\text { practice in } \\
\text { school forest } \\
\text { - Finding emotion } \\
\text { card in forest }\end{array}$ & $\begin{array}{l}\text { Finding objects in } \\
\text { school forest } \\
\text { reflecting my } \\
\text { emotion } \\
\text { - Expressing } \\
\text { sympathy with } \\
\text { friend's emotion }\end{array}$ & $\begin{array}{l}\text { Communication } \\
\text { practice in } \\
\text { classroom }\end{array}$ & $\begin{array}{l}\text { - Identifying my } \\
\text { emotion. } \\
\text { - Expressing } \\
\text { sympathy with } \\
\text { friend's emotion }\end{array}$ \\
\hline & 6 & $\begin{array}{l}\text { Emotion } \\
\text { regulation }\end{array}$ & & $\begin{array}{l}\text { - Meditation in } \\
\text { school forest }\end{array}$ & $\begin{array}{l}\text { - Meditation in } \\
\text { school forest }\end{array}$ & $\begin{array}{l}\text { - Meditation in } \\
\text { classroom }\end{array}$ & $\begin{array}{l}\text { Meditation in a } \\
\text { classroom }\end{array}$ \\
\hline
\end{tabular}

TSHPP=Traditional school health promotion program.

the school forest group showed significant improvement in hyperactivity, whereas the TSHPP group showed significant improvement in health promoting behavior and social relationship after the intervention. In summary, hypothesis 1 was partially supported (Table 3 ).

\section{Comparisons of Changes of Pre and Post Programs between Two Groups}

Comparing the two groups' post-pre difference scores, the two groups differed significantly in social relationship $(\mathrm{t}=3.14, p=.002)$. Regarding post-pre difference scores, school forest program was more effective than TSHPP only in LF $(\mathrm{t}=2.17, p=.034), \mathrm{HF}(\mathrm{t}=2.17, p=.034)$ and mean heart rate $(\mathrm{t}=3.23, p=.002)$. In summary, hypothesis 2 was supported just in $\mathrm{LF}, \mathrm{HF}$, and mean heart rate.

Both programs significantly improved in physical and mental health in some aspects, and school forest program was more effective only in improving mental health.

\section{DISCUSSION}

This study was conducted to compare the effects of two different school-based intervention programs-the school forest program and the TSHPP-on physical and mental health among elementary school students. Overall, both intervention programs showed positive effects on physical and mental health among elementary school students. Concerning physical health, both programs showed significant beneficial effects on body fat percentage; this effect was more prominent in the TSHPP group. Only the TSHPP program showed a significant beneficial effect on BMI after the intervention. Previous studies have reported positive effects of school-based health promotion programs on decreasing BMI and improving eating habits among elementary school children[24,25]. The effect of the TSHPP on urban children's physical health was particularly significant, as children from urban areas, who often have a more sedentary lifestyle than children from rural areas, may respond dramatically to school-based health promotion programs. 
Table 2. Homogeneity of General Characteristics and Examined Variables at Baseline

\begin{tabular}{|c|c|c|c|c|c|}
\hline \multirow{2}{*}{ Variables } & \multirow{2}{*}{ Categories } & \multirow{2}{*}{$\begin{array}{c}\text { School forest group }(n=21) \\
n(\%) \text { or } M \pm S D\end{array}$} & \multirow{2}{*}{$\begin{array}{c}\text { TSHPP group }(n=52) \\
n(\%) \text { or } M \pm S D\end{array}$} & \multirow{2}{*}{$x^{2}$ or $\mathrm{t}$} & \multirow{2}{*}{$p$} \\
\hline & & & & & \\
\hline \multirow[t]{2}{*}{ Gender } & Boy & $14(66.7)$ & $24(46.2)$ & \multirow[t]{2}{*}{2.52} & \multirow[t]{2}{*}{.112} \\
\hline & Girl & $7(33.3)$ & $28(53.8)$ & & \\
\hline \multirow[t]{2}{*}{ Grade } & 4 th grade & $14(66.7)$ & $26(50.0)$ & \multirow[t]{2}{*}{1.68} & \multirow[t]{2}{*}{.195} \\
\hline & 5 th grade & $7(33.3)$ & $26(50.0)$ & & \\
\hline \multirow{3}{*}{ Economic status } & High & $13(61.9)$ & $24(46.2)$ & \multirow[t]{3}{*}{1.56} & \multirow[t]{3}{*}{.451} \\
\hline & Middle & $7(33.3)$ & $25(48.1)$ & & \\
\hline & Low & $1(4.8)$ & $3(5.8)$ & & \\
\hline Height & & $139.11 \pm 6.03$ & $141.51 \pm 8.60$ & -1.16 & .249 \\
\hline Weight & & $36.45 \pm 10.26$ & $38.19 \pm 9.36$ & $-0.93^{*}$ & $.354^{*}$ \\
\hline Body mass index & & $18.63 \pm 3.99$ & $18.87 \pm 3.22$ & $-0.70^{*}$ & $.487^{*}$ \\
\hline Body fat percentage & & $23.90 \pm 9.16$ & $23.62 \pm 8.13$ & -0.15 & .884 \\
\hline \multirow[t]{4}{*}{ HRV } & Norm LF & $0.51 \pm 0.17$ & $0.48 \pm 0.14$ & 0.68 & .499 \\
\hline & Norm HF & $0.49 \pm 0.17$ & $0.52 \pm 0.14$ & -0.68 & .499 \\
\hline & $\mathrm{LF} / \mathrm{HF}$ & $1.47 \pm 1.58$ & $1.11 \pm 0.76$ & $-0.24^{*}$ & $.807^{*}$ \\
\hline & Mean HR & $89.53 \pm 13.76$ & $87.59 \pm 10.10$ & $-0.09^{*}$ & $.932^{*}$ \\
\hline Health promoting behavior & & $107.95 \pm 14.27$ & $103.35 \pm 12.94$ & 1.34 & .186 \\
\hline Depression & & $7.43 \pm 8.30$ & $10.94 \pm 7.65$ & $-2.45^{*}$ & $.014^{*}$ \\
\hline Hyperactivity & & $13.71 \pm 9.47$ & $17.94 \pm 11.06$ & $-1.68^{*}$ & $.093^{*}$ \\
\hline Social relationship & & $110.57 \pm 15.54$ & $108.15 \pm 10.35$ & 0.78 & .440 \\
\hline
\end{tabular}

*Mann-Whitney U test; TSHPP=Traditional school health promotion program; HRV=Heart rate viability; Norm LF=Normalized low frequency; Norm HF=Normalized high frequency; HR=Heart rate.

On the other hand, the school forest program was particularly effective in decreasing hyperactivity and increasing relaxation indicated by normalized $\mathrm{LF}$, normalized $\mathrm{HF}$, and mean heart rate in HRV. Previous studies examining adults have also reported that the effect of intervention programs on relaxation was strengthened when the programs were conducted in a forest, rather than in a city[21,25]. Similarly, recent studies examining children have reported that forest therapy effectively alleviates depression, anxiety, and anger $[26,27]$. Additionally, school forest programs have been found to lead students to become more interested in nature [14]. It is possible that the soothing effect of the school forest program, delivered in nature, promoted relaxation and decreased hyperactivity in the present study. Decreased hyperactivity, which was observed in the present study, has significant implications regarding the improvement of attention deficit hyperactivity disorder (ADHD) symptoms. ADHD symptoms and stress have been found to predict levels of depression in elementary school students[7].

Regarding mental health, children in both programs showed significant improvement in depression scores after the intervention. In addition, the TSHPP was found to be effective in improving social relationship among children.
Various school-based health promotion programs have been found to improve children's ability to regulate emotions and social stress, and social and communication skills [28-30]. It is not clear, however, why only the TSHPP was found to be effective in improving social relationship among children. Further studies, examining more representative samples, are required to provide clearer explanations of the effect of school-based health promotion programs on social relationship.

Several limitations of the present study require mention. First, two groups were not comparable in sizes due to the difficulties in recruitment, and small sample size was another limitation of the present study. Second, recruiting participants in two different schools, we cannot ignore unexpected effect and factors caused by two different regions.

For the present study, we compared the effects of TSHPP and school forest program on elementary school children. Both programs significantly decreased body fat percentage; this effect was more prominent in the TSHPP group. In addition, the TSHPP was found to improve BMI, health promoting behavior, depression, and social relationships. On the other hand, the school forest program was more effective in decrease hyperactivity and increase relaxation among 
Table 3. Comparisons of Changes in Physical and Mental Health Variables between School Forest Group and TSHPP Group

\begin{tabular}{|c|c|c|c|c|c|c|c|c|c|c|}
\hline \multirow{2}{*}{\multicolumn{2}{|c|}{ Variables }} & \multirow{2}{*}{ Categories } & \multicolumn{3}{|c|}{ School forest group $(n=21)$} & \multicolumn{3}{|c|}{ TSHPP group $(n=52)$} & \multirow[b]{2}{*}{$t$} & \multirow{2}{*}{$p$} \\
\hline & & & $\mathrm{M} \pm \mathrm{SD}$ & $d_{E}$ & $\mathrm{t}(p)$ & $\mathrm{M} \pm \mathrm{SD}$ & $\mathrm{d}_{\mathrm{C}}$ & $\mathrm{t}(p)$ & & \\
\hline \multicolumn{2}{|l|}{ BMI } & $\begin{array}{l}\text { Pre } \\
\text { Post }\end{array}$ & $\begin{array}{l}18.63 \pm 3.99 \\
18.41 \pm 3.90\end{array}$ & -0.22 & $\begin{array}{l}-2.01 \\
(.058)\end{array}$ & $\begin{array}{l}18.90 \pm 3.19 \\
18.50 \pm 3.16\end{array}$ & -0.40 & $\begin{array}{c}-6.31 \\
(<.001)\end{array}$ & 1.43 & .158 \\
\hline \multicolumn{2}{|c|}{ Body fat percentage } & $\begin{array}{l}\text { Pre } \\
\text { Post }\end{array}$ & $\begin{array}{l}23.90 \pm 9.16 \\
22.92 \pm 9.82\end{array}$ & -0.98 & $\begin{array}{l}-2.47 \\
(.023)\end{array}$ & $\begin{array}{l}23.57 \pm 8.15 \\
20.92 \pm 8.53\end{array}$ & -2.65 & $\begin{array}{c}-8.12 \\
(<.001)\end{array}$ & 2.96 & .004 \\
\hline \multirow[t]{4}{*}{ HRV } & Norm LF & $\begin{array}{l}\text { Pre } \\
\text { Post }\end{array}$ & $\begin{array}{l}0.51 \pm 0.17 \\
0.47 \pm 0.12\end{array}$ & -0.04 & $\begin{array}{l}-1.03 \\
(.317)\end{array}$ & $\begin{array}{l}0.48 \pm 0.14 \\
0.53 \pm 0.15\end{array}$ & 0.05 & $\begin{array}{c}2.37 \\
(.022)\end{array}$ & 2.17 & .034 \\
\hline & Norm HF & $\begin{array}{l}\text { Pre } \\
\text { Post }\end{array}$ & $\begin{array}{l}0.49 \pm 0.17 \\
0.53 \pm 0.12\end{array}$ & 0.04 & $\begin{array}{c}1.03 \\
(.317)\end{array}$ & $\begin{array}{l}0.52 \pm 0.14 \\
0.47 \pm 0.15\end{array}$ & -0.05 & $\begin{array}{l}-2.37 \\
(.022)\end{array}$ & 2.17 & .034 \\
\hline & $\mathrm{LF} / \mathrm{HF}$ & $\begin{array}{l}\text { Pre } \\
\text { Post }\end{array}$ & $\begin{array}{l}1.47 \pm 1.58 \\
0.98 \pm 0.43\end{array}$ & -0.49 & $\begin{array}{l}-1.41 \\
(.173)\end{array}$ & $\begin{array}{l}1.11 \pm 0.76 \\
1.40 \pm 0.89\end{array}$ & 0.29 & $\begin{array}{c}2.23 \\
(.030)\end{array}$ & $1.90^{*}$ & $.057^{*}$ \\
\hline & mean HR & $\begin{array}{l}\text { Pre } \\
\text { Post }\end{array}$ & $\begin{array}{l}89.53 \pm 13.76 \\
80.54 \pm 9.17\end{array}$ & -8.99 & $\begin{array}{l}-3.67 \\
(.002)\end{array}$ & $\begin{array}{l}87.59 \pm 10.10 \\
87.30 \pm 10.14\end{array}$ & -0.29 & $\begin{array}{l}-0.21 \\
(.834)\end{array}$ & 3.23 & .002 \\
\hline \multicolumn{2}{|c|}{$\begin{array}{l}\text { Health promoting } \\
\text { behavior }\end{array}$} & $\begin{array}{l}\text { Pre } \\
\text { Post }\end{array}$ & $\begin{array}{l}107.95 \pm 14.27 \\
110.67 \pm 19.05\end{array}$ & 2.72 & $\begin{array}{c}0.80 \\
(.436)\end{array}$ & $\begin{array}{l}103.35 \pm 12.94 \\
109.06 \pm 14.89\end{array}$ & 5.71 & $\begin{array}{c}3.79 \\
(<.001)\end{array}$ & $0.54^{*}$ & $.587^{*}$ \\
\hline \multicolumn{2}{|c|}{ Depression } & $\begin{array}{l}\text { Pre } \\
\text { Post }\end{array}$ & $\begin{array}{l}7.43 \pm 8.30 \\
5.48 \pm 7.45\end{array}$ & -1.95 & $\begin{array}{l}-2.96 \\
(.008)\end{array}$ & $\begin{array}{r}10.94 \pm 7.65 \\
8.50 \pm 7.31\end{array}$ & -2.44 & $\begin{array}{l}-3.54 \\
(.001)\end{array}$ & $0.48^{*}$ & $.629^{*}$ \\
\hline \multicolumn{2}{|c|}{ Hyperactivity } & $\begin{array}{l}\text { Pre } \\
\text { Post }\end{array}$ & $\begin{array}{c}13.71 \pm 9.47 \\
9.67 \pm 10.12\end{array}$ & -4.04 & $\begin{array}{l}-2.84 \\
(.010)\end{array}$ & $\begin{array}{l}17.94 \pm 11.06 \\
15.31 \pm 14.08\end{array}$ & -2.63 & $\begin{array}{l}-1.848 \\
(.070)\end{array}$ & $0.28^{*}$ & $.784^{*}$ \\
\hline \multicolumn{2}{|c|}{ Social relationship } & $\begin{array}{l}\text { Pre } \\
\text { Post }\end{array}$ & $\begin{array}{l}110.57 \pm 15.54 \\
109.19 \pm 18.16\end{array}$ & -1.38 & $\begin{array}{l}-0.51 \\
(.618)\end{array}$ & $\begin{array}{l}108.15 \pm 10.35 \\
116.10 \pm 13.16\end{array}$ & 7.95 & $\begin{array}{c}5.08 \\
(<.001)\end{array}$ & $3.14^{*}$ & $.002^{*}$ \\
\hline
\end{tabular}

*Mann-Whitney $\mathrm{U}$ test; $\mathrm{d}_{\mathrm{E}}=$ Mean differences in the experimental group; $\mathrm{d}_{\mathrm{C}}=$ Mean differences in the comparison group; BMI=Body mass index; TSHPP=Traditional school health promotion program; HRV=Heart rate viability; Norm LF=Normalized Low frequency; Norm HF=Normalized High frequency; $\mathrm{HR}=$ Heart rate.

elementary school students. Even if the two health promotion programs produced unique health outcomes and both of them were found to promote both physical and mental health among school-aged children.

Considering the differing effects of the two programs, it is necessary to test the programs with larger and more diverse groups of children. Additionally, we suggest that further studies take more diverse physiological measurements, such as levels of vitamin D and stress hormones, to test the unique effects of school forest programs.

\section{CONCLUSION}

The present study provides preliminary evidence of the positive and differing effects of two different school-based health promotion programs on school-aged children's physical and mental health. These findings may serve as a foundation for further development of various school-based health promotion programs for elementary school students, particularly programs delivered in forested areas.

\section{REFERENCES}

1. Heer H, Koehly L, Pederson R, Morera O. Effectiveness and spillover of an after-school health promotion program for Hispanic elementary school children. American Journal of Public Health. 2011;101(10):1907-1913. http://dx.doi.org/10.2105/ajph.2011.300177

2. Dobbins M, Husson H, DeCorby K, LaRocca R. School-based physical activity programs for promoting physical activity and fitness in children and adolescents aged 6 to 18. Cochrane Database Systematic Review. 2013;28(2):1-260. http://dx.doi.org/10.1002/14651858.CD007651.pub2

3. Kim BM, Jung H, Park H. Effects of self-efficacy promotion program on obesity in elementary school children. The Journal of the Korean Society of School Health. 2009;22(1):119-128.

4. Bae J. The influence of the laughing programs on self-esteem and stress coping behaviors in elementary school student. The Journal of the Korean Society of School Health. 2015;28(1): 22-30. http://dx.doi.org/10.15434/kssh.2015.28.1.22

5. Lee S, Kim C, Kim D. A meta-analysis of the effect of schoolbased anti-bullying programs. Journal of Child Health Care. 
2013;19(2):136-153.

http://dx.doi.org/10.1177/1367493513503581

6. Ahn Y, Choi S, Sohn M. Adiposity of Korean school-age children measured by national and international growth charts. Research in Nursing \& Health. 2013;36(1):16-25. http://dx.doi.org/10.1002/nur.21510

7. Mo S, Kim H, Lee S, Kim J, Yoon K. Study on the policy for mental health promotion of children and adolescents III: Combined report. Policy Research Report. Seoul: National Youth Policy Institute; 2013 December. Report No.: Research Report 13-R16.

8. Lee S, Oh I, Lee J. Psychosocial characteristics of bullies, victims, bully-victims among elementary school students. Korean Journal of Youth Studies. 2014;21(5);391-416.

9. Maas J, Verheij R, Groenewegen P, Vries S, Spreeuwenberg P. Green space, urbanity, and health: How strong is the relation? Journal of Epidemiology and Community Health. 2006;60(7): 587-592. http://dx.doi.org/10.1136/jech.2005.043125

10. Lee J, Tsunetsugu Y, Takayama N, Park B, Li Q, Song C, et al. Influence of forest therapy on cardiovascular relaxation in young adults. Evidence-Based Complementary and Alternative Medicine. 2014;2014(2014):1-7. http://dx.doi.org/10.1155/2014/834360

11. Morita E, Fukuda S, Nagano J, Hamajima N, et al. Psychological effects of forest environments on healthy adults: Shinrinyoku [forest air bathing, walking] as a possible method of stress reduction. Public Health. 2007;121(1):54-63. http://dx.doi.org/10.1016/j.puhe.2006.05.024

12. Shin $W$. The influence of forest view through a window on job satisfaction and job stress. Scandinavian Journal of Forest Research. 2007;22(3):248-253. http://dx.doi.org/10.1080/02827580701262733

13. Yu J, Park C. The influence of forest activities on elementary school students' changes in the awareness of forest. Korean Journal of Environmental Ecology. 2015;29(3):462-473.

14. Kuk J, Yoon Y, Park B, Kim W. Effects of school forest on elementary students' satisfaction with school landscape and environmental education. Journal of Korean Society for Plants, People and Environment. 2008;11(3):27-34.

15. Kovacs M. The children's depression inventory (CDI). Psychopharmacology Bulletin. 1985;21(4):995-998.

16. Cho S, Lee Y. Development of the Korean form of the Kovacs children's depression inventory. Journal of Korean Neuropsychiatry Association. 1990;29(4):943-956.

17. Bahn G, Shin M, Cho S, Hong K. A preliminary study for the development of the assessment scale for ADHD in adolescents: Reliability and validity for CASS(S). Journal of the Korean Academy of Child and Adolescent Psychiatry. 2001;12 (2):218224.
18. Bae S. Effect of laborious working learning programs on elementary school students' sociality development [master's thesis]. Incheon: Gyeongin National University of Education; 2005. p. 1-111.

19. Choi K. A study on children's self-concept and sociality according to parents' rearing attitude and teachers' guidance attitude [master's thesis]. Seoul: Hanyang University; 2007. p. 1-71.

20. Walker SN, Sechrist KR, Pender NJ. The health-promoting lifestyle profile: Development and psychometric characteristics. Nursing Research. 1987;36(2):76-81. http://dx.doi.org/10.1097/00006199-198703000-00002

21. Kim M, Chung Y. A study on the relations of health promoting daily life style and self-efficiency about boys' obesity. ChungAng Journal of Nursing. 2000;4:93-119.

22. Choi WS. Heart rate variability and the measurement of stress. The Korean Journal of Stress Research. 2005;13(2):59-63.

23. Lee I, Bang KS, Kim S, Choi H, Hwang I. Effects of a health promotion program on elementary students' physical and mental health. Open Journal of Nursing. 2015;5(9):805-812. http://dx.doi.org/10.4236/ojn.2015.59085

24. Harris KC, Kuramoto LK, Schulzer M, Retallack JE. Effect of school-based physical activity interventions on body mass index in children: A meta-analysis. Canadian Medical Association Journal. 2009;180(7):719-726.

http://dx.doi.org/10.1503/cmaj.080966

25. Lee J, Park B, Tsunetsugu Y, Ohira T, Kagawa T, Miyazaki Y. Effect of forest bathing on physiological and psychological responses in young Japanese male subjects. Public Health. 2011; 25(2):93-100. http://dx.doi.org/10.1016/j.puhe.2010.9.005

26. Cho Y, Shin W, Yeoun P, Lee H. The influence of forest experience program on children from low income families, sociality and depression. The Journal of Korean Institute of Forest Recreation. 2011;15(2):69-75.

27. Kim I, Yeoun P, Shin W, Kim I. The influence of a forest experience program on elementary school students' anger. The Journal of Korean Institution of Forest Recreation. 2013;17(2):55-61.

28. Park J, Lee J, Jeong Y. The effects of love-the-trees experience activities program on development of the personality and sociality to elementary students. Journal of Korean Practical Arts Education. 2010;23(4):205-221.

29. Lee I, Kang Y. The effects of conflict resolution program on the conflict resolution method and sociability of elementary school senior student. The Journal of the Korean Association on Developmental Disabilities. 2007;11(2):141-159.

30. Lee $Y$, Ryu W, Jeong H. The effect of classroom-based nonviolent communication training program on middle school students' communication and peer relationships. The Korean Journal of East-West Science. 2009;12(2):47-57. 